\title{
O BEIJÓDROMO DE DARCY E LELÉ: UM PRESENTE PARA BRASÍLIA*
}

Cláudia Estrela Porto

\section{Resumo}

Darcy Ribeiro nunca escondeu de ninguém que acalentava o sonho de ver construída a sede definitiva de sua Fundação no campus da Universidade de Brasília (UnB). Para tanto, contanto com o apoio de Oscar Niemeyer, encomendou o projeto ao arquiteto João Filgueiras Lima. A rigor, Darcy Ribeiro pediu ao Lelé "apenas" o "projeto de uma biblioteca" para acolher o seu acervo de livros, mobiliário particular e a rica coleção de arte plumária de sua primeira mulher, Berta Ribeiro. De 1996 a 2010, Lelé desenvolveu o projeto que, com o tempo e a colaboração do próprio Darcy, foi sendo aperfeiçoado, de modo a refletir claramente o pensamento dos dois criadores. Nasceu de tal parceria a sede da Fundação Darcy Ribeiro com o "beijódromo", erguida no coração da UnB. Uma edificação circular em dois pavimentos, com 32,20m de diâmetro interno e $37 \mathrm{~m}$ de diâmetro de cobertura, tal como uma tenda de circo (ou uma maloca indígena, como preferia Darcy), que se lança para o alto em sua parte central e acolhe um espaço circular ajardinado, de $12 \mathrm{~m}$ de diâmetro e pé-direito duplo. Trata-se de uma obra singular. Não apenas um memorial. Lelé soube desenhar o sonho de Darcy. Uma "espaçonave" que descansa suavemente em solo universitário, contendo e preservando o pensamento de Darcy Ribeiro.

Palavras-chave: Beijódromo, Lelé, Darcy Ribeiro

Abstract: Darcy Ribeiro never hid the fact that he dreamed of building the final head office of his foundation in Brasilia's University (UnB). For such, together with Niemeyer's support, he commissioned architect João Filgueiras Lima (Lelé) the project. Initially, Darcy Ribeiro just asked for a library to organize his books, particular furniture and his first wife's - Berta Ribeiro - rich collection of plume art. From 1996 to 2010 Lelé developed the project's design which was improved by Darcy himself in such a way that it turned out to be a reflection of both's thinking manner. From this partnership, the Darcy Ribeiro Foundation was born with the building "beijódromo", located in UnB's heart. It is a two-floor circular building, 32.2 meters of intern diameter and 37 meters of roofing, similar to a circus tent (or as an indian house, as Darcy preferred), that grows up in its central part and receives a circular gardened space of 12 meters in diameter and a double-ceiling height. It is a singular, particular work. It is not just a memorial. Lelé had known how to draw Darcy's dream. It is a spaceship that rises on university ground, containing and conserving Darcy Ribeiro's thoughts.

Key-words: Beijódromo, Lelé, Darcy Ribeiro
Trabalho apresentado no $1^{\circ}$ EANPARQ, Rio de Janeiro, 2010. 


\section{DO ACASO NASCE UMA BELA AMIZADE}

"A vida da gente, no fundo, é movida por questões acidentais. A gente planeja, planeja e tudo sai ao contrário. O segredo é deixar as coisas acontecerem" ${ }^{\prime \prime}$, filosofa ${ }^{1}$ LIMA, João Filgueiras. "Esse é Lelé”. Trip. São Paulo, no 185, Fevereiro, 2010, p. 13.

${ }^{2}$ Lelé iniciou o curso de arquitetura em 1951 e se formou em 1955 pela antiga Universidade do Brasil (hoje, UFRJ), no Rio de Janeiro.

3 O pintor e arquiteto Aldary Henriques Toledo (1915-1998) foi discípulo de Portinari, com quem estudou entre 1932 e 1935 . Na década de 1950, já era um arquiteto reconhecido pelo conjunto de obras modernistas que projetara com Oscar Niemeyer, Francisco Bolonha, Luiz Góes Telles, Edgar Guimarães do Valle e Gilberto Lyra Lemos, na cidade mineira de Cataguazes.

${ }^{4}$ Darcy Ribeiro (1922-1997), antropólogo e educador, nasceu em Montes Claros (MG). Atuou como indigenista e dedicou-se à educação primária e superior. Em 1962, fundou a Universidade de Brasília, da qual foi o primeiro reitor. Foi Ministro da Educação e Ministro-Chefe da Casa Civil no governo do presidente João Goulart (19611964), vice-governador do Rio de Janeiro, no primeiro governo de Leonel Brizola (1983-1987) e senador (de 1991 até sua morte).

${ }^{5}$ Era o ano de 1951.

${ }^{6}$ Inaugurado em 19 de abril de 1953.

${ }^{7}$ LIMA, João Filgueiras. O que é ser arquiteto: memórias profissionais de Lelé (João Filgueiras Lima). Entrevista a Cynara Menezes. Rio de Janeiro: Record, 2004, p. 24.
João da Gama Filgueiras Lima, o Lelé, para quem a vida profissional se deve a uma sucessão de acasos.

Todos de certa forma ligados a amigos que surgiram inesperadamente em sua vida, tecendo o fio invisível de uma trama que o levaria, nos últimos 50 anos, a ser reconhecido como um dos melhores arquitetos brasileiros, com uma obra repleta de beleza, funcionalismo, tecnologia e mestria.

Sim, ele poderia ter se tornado músico, e a arquitetura brasileira perderia um de seus maiores expoentes. Mas o acaso fez com que cursasse arquitetura e, quando ainda estudante ${ }^{2}$, conhecesse o arquiteto Aldary Toledo ${ }^{3}$, por quem seria - "com ele, aprendi que arquitetura podia ser arte”, diz. Aldary Toledo também the proporcionou uma oportunidade de emprego, como desenhista no IAPB (Instituto de Aposentadoria e Pensão dos Bancários), onde era funcionário. E o encontro com Darcy Ribeiro ${ }^{4}$, que um dia $^{5}$ veio ao escritório de Aldary Toledo ver o projeto do Museu do Índio ${ }^{6}$, que havia idealizado para ser construído no Rio de Janeiro. Este primeiro contato, embora breve, causa profunda impressão em Lelé: "Darcy era uma pessoa exuberante, com uma formação intelectual incrível fortemente influenciado intelectualmente e com uma forma de se exprimir, eloqüentemente, rapidamente, que deixava a gente quase asfixiado, tonto. Eu, aos 20 e poucos anos, tomei um susto quando vi aquela figura. Mas, ao mesmo tempo, simpatizamos de imediato"?.

Lelé não sabia ainda, mas o destino poria Darcy Ribeiro novamente em seu caminho. Recém formado, já como arquiteto do IAPB, Lelé se candidata para vir para Brasília. "Fui recebido inicialmente por Nauro Esteves, chefe do escritório de Oscar. Nauro, apesar de seu temperamento introvertido e seco no trato com outros profissionais, foi convincente ao me estimular a participar daquela aventura. Já Oscar, em tom de brincadeira, enalteceu minha coragem"8. Destemido, Lelé desembarca em Brasília em 1957 com a incumbência de construir os onze blocos de apartamentos do IAPB, projetados por Niemeyer e executados pelas empresas ECG (Empresa de Construções Gerais) e ECISA (Engenharia, Comércio e Indústria), a SQS 108. Foi nesta época que Lelé começou a desenvolver habilidades do ofício de engenheiro na busca de soluções construtivas para os problemas que surgiam no caótico canteiro de obras desse período. $\mathrm{O}$ rigor e a busca de soluções inovadoras tornaram-se uma constante.

Em 1960, no mesmo ano da inauguração da nova capital, o presidente Juscelino Kubitschek solicitou ao Congresso Nacional a criação da Universidade de Brasília e, em 1961, o presidente João Goulart sancionou a lei ${ }^{9}$ que autorizou o Poder Executivo a estabelecer a Fundação 
Universidade de Brasília. Darcy Ribeiro, um de seus mentores ${ }^{10}$, torna-se o seu primeiro reitor em $1962 \mathrm{e}$, sabendo do talento e aplicação técnica de Lelé, o convida a vir para a $\mathrm{UnB}^{11}$.

Lelé, porém, só aceitaria o convite se viesse por intermédio de Oscar Niemeyer, com quem estava comprometido. Logo surge a oportunidade, quando Niemeyer assume o curso de Arquitetura e Urbanismo da $\mathrm{UnB}^{12}$. Diz ele:

\begin{abstract}
"Passei a trabalhar diretamente com Oscar em 1961, após a inauguração da cidade. Ele convocou-me inicialmente para chefiar o DUA ${ }^{13}$, ocupando o lugar de $\mathrm{Nauro}^{14}$ que havia se afastado de Brasília. Devido às dificuldades criadas pela então Prefeitura de Brasília para a minha contratação, Oscar resolveu me indicar para a Secretaria Executiva do Ceplan (Centro de Planejamento da Universidade de Brasília). Foi um período de muito trabalho. Além de acompanhar os projetos e construções da universidade recém criada por Darcy Ribeiro, assumi também o setor de tecnologia do curso de arquitetura"15.
\end{abstract}

Com a universidade que estava nascendo, cresce a proximidade com Darcy Ribeiro, uma vez que Oscar Niemeyer viajava muito neste período. Devido à urgência de um programa imposto pelo próprio Darcy, os arquitetos do Ceplan optaram pela industrialização dos componentes. Se, inicialmente Lelé atuou, ao lado de Oscar Niemeyer, no projeto e construção dos Pavilhões de Serviços Gerais, no Instituto Central de Ciências
(ICC) e no Instituto de Teologia, cabe

a ele o mérito de um sistema construtivo inovador, em tecnologia de concreto pré-fabricado e protendido, utilizado para os Galpões de Serviços Gerais ${ }^{\mathbf{1 6}} \mathrm{e}$ para os primeiros blocos de apartamentos de professores da Colina ${ }^{17}$. Nascia, com a UnB e com Lelé, um dos maiores canteiros de pré-fabricação da América Latina.

A relação de Lelé com Darcy Ribeiro é pontuada por episódios, no mínimo, engraçados. Ainda nos primeiros anos da UnB, Darcy, querendo se estabelecer em Brasilia, solicitou a Lelé que lhe fizesse o projeto de uma casa com os restos de demolição de outra residência que havia adquirido em Montes Claros. Lelé chegou mesmo a ir à cidade enumerar as belas peças de madeira maciça com as quais fez o projeto que, infelizmente, não foi construído. Inicialmente, a casa teve de aguardar pelo acúmulo de trabalho de Darcy, que foi trabalhar direto com o presidente João Goulart. Depois, com o golpe militar de abril de 1964, Darcy Ribeiro teve de se exilar do país e Lelé se demitiu da UnB com outros 223 professores.

Porém, fizeram vários outros projetos juntos. Em 1982, quando Darcy Ribeiro retorna do exílio e se torna vice-governador do Rio de Janeiro, Lelé estava em Abadiânia, pequena cidade do interior de Goiás, desenvolvendo as primeiras experiências em argamassa armada, com a produção de uma mini-usina ${ }^{18} \mathrm{de}$ pré-moldados leves para a construção de escolas rurais e pontes para estradas vicinais. Lelé havia decidido fechar seu
${ }^{8}$ LIMA, João Filgueiras. "Crônicas de Brasília 1957/1961”. AU Arquitetura e Urbanismo. São Paulo, n ${ }^{\circ}$ 192, Março, 2010, p. 68.

9 BRASIL. Lei no 3998, de 15 de dezembro de 1961. Autoriza o Poder Executivo a instituir a Fundação Universidade de Brasília, e dá outras providências.

10 Os outros membros que compunham a comissão encarregada de pensar a nova Universidade eram Cyro dos Anjos, Oscar Niemeyer e Alcides da Rocha Miranda.

${ }^{11}$ Universidade de Brasília.

12 Inicialmente, Alcides da Rocha Miranda, que havia feito o primeiro projeto arquitetônico da $\mathrm{UnB}$, o auditório Dois Candangos, estava cogitado para assumir o cargo.

13 Departamento de Arquitetura e Urbanismo da Novacap.

${ }^{14}$ Arquiteto Nauro Esteves.

15 LIMA, João Filgueiras, op. cit., p. 71.

161962 (projeto), 1964-1965 (construção do SG-11 e SG-12), 1968 (adaptação funcional - Tecnologia) e 1969 (construção do SG09). O prédio SG-9 foi construído em 1969 - em alvenaria convencional - para abrigar a Oficina Mecânica da Faculdade de Tecnologia pela construtora ENAR.

${ }^{17} 1962$ (projeto) e 1963 (construção).

18 A fábrica de Abadiânia funcionou de 1982 a 1984. 
${ }^{19}$ A Fábrica de Escolas e Equipamentos Urbanos do Rio de Janeiro funcionou de 1984 a 1986 e a Fábrica de Equipamentos Comunitários do Rio de Janeiro, da prefeitura, usando a tecnologia do Lelé, de 1985 a 1989.

$20 \mathrm{Na}$ Fábrica de Equipamentos Urbanos de Brasília (1985-1990).

${ }^{21}$ Fernando Collor de Mello, presidente do Brasil entre 1990 e 1992.

${ }^{22}$ Inicialmente, o acervo permaneceu na antiga residência de Darcy Ribeiro em Copacabana, e atualmente encontra-se na sede da FUNDAR, em Santa Tereza, Rio de Janeiro.

${ }^{23}$ FUNDAÇÃO DARCY RIBEIRO. Disponível em: < http://www. fundar.org.br/>. Acesso em 7 de jutho 2010. escritório particular em Brasília e dirigir sua experiência profissional aos programas públicos de cunho social. Em 1984, Darcy Ribeiro toma conhecimento da pequena "fábrica de escolas" de Abadiânia e vai visitá-la, acompanhado do governador do Rio de Janeiro, Leonel Brizola. A conseqüência desse encontro foi a transferência de Lelé para o Rio de Janeiro, onde fundou uma potente usina de pré-fabricação em argamassa armada, realizando inúmeras obras em comunidades carentes e bairros periféricos, com o mesmo esmero arquitetônico que caracteriza a sua produção. Foi a Fábrica de Escolas ${ }^{19}$, montada por Lelé com apoio de Darcy Ribeiro, que permitiu a construção de 200 escolas e 90 creches no período de dois anos, além de centros comunitários, postos de saúde, canais de drenagem para a Baixada Fluminense, abrigos de ônibus e outros equipamentos de mobiliário urbano.

Em 1990, Darcy Ribeiro procurou novamente Lelé, desta vez propondo-lhe um programa ousadíssimo: construir cerca de 5000 edificações para atendimento integral às crianças, reunindo em cada conjunto arquitetônico a escola, a creche, o posto de saúde, o centro comunitário e o ginásio de esportes. Desta vez, o projeto deveria ser implementado em todo o território nacional e no prazo de quatro anos. Seriam os Centros Integrados de Atenção à Criança, os CIAC's. O programa, rigorosamente planejado, comprovou a sua viabilidade técnica e administrativa, o prédio piloto tendo sido construído, inclusive, em Brasília ${ }^{20}$, e paralelamente no Rio de Janeiro, orientando e iniciando a produção das demais fábricas licitadas, distribuídas estrategicamente pelo Brasil. Porém, contingências político-administrativas do governo Collor ${ }^{21}$ levam Lelé a se desligar da liderança do projeto, conduzindo à imediata renúncia de toda a equipe técnica que o acompanhava.

Em 1996, já debilitado pelo câncer, Darcy Ribeiro recorre ao Lelé para a realização do último desejo. Acabara de criar a Fundação que leva o seu nome e gostaria, rapidamente, de ver concretizado o projeto de sua sede definitiva.

\section{O SONHO BURILADO}

Darcy Ribeiro nunca escondeu de ninguém que acalentava o sonho de ver construída a sua fundação no campus da UnB. Enquanto isto não fosse possível, a Fundação Darcy Ribeiro manteria seu acervo em outras dependências ${ }^{22}$. $\mathrm{O}$ primeiro parágrafo do Estatuto de sua criação, de 11 de janeiro de 1996, estipula:

“A Fundação terá como núcleo (base) principal de trabalho a área que lhe será destinada por Universidade Pública a ser definida pelo Presidente, onde instalarão para uso acadêmico a Biblioteca DARCY RIBEIRO, seus arquivos e os de Berta Gleizer Ribeiro"23.

A rigor, Darcy Ribeiro pediu ao Lelé "apenas" o "projeto de uma biblioteca" para acolher o seu acervo de livros, mobi- 
liário e a rica coleção de arte plumária de sua primeira mulher, a também antropóloga Berta Ribeiro. Tinha a intenção de doar tudo para a UnB. A idéia do "beijódromo" veio depois. Como não podia se deslocar a Salvador, onde Lelé trabalhava, solicitou ao Aloysio Campos da $\mathrm{Paz}^{24}$ uma ligação direta, através da Rede Sarah, por vídeo-conferência.

E foi assim, olho no olho, interagindo diretamente com Lelé, que Darcy Ribeiro lhe explicou o programa e o que desejava. A sintonia entre os dois amigos era tão forte que bastou poucas palavras para surgir uma primeira proposta, que Lelé fez questão de entregar pessoalmente ao Darcy, acompanhada de uma pequena maquete para melhor compreensão do espaço.

Embora a criação do projeto e a elaboração do desenho sejam de Lelé, o projeto reflete a dicotomia entre o passado e o modo de ser de Darcy Ribeiro. Segundo o arquiteto, tanto pode lembrar um disco voador (o lado empreendedor de Darcy) como uma maloca indígena (o lado antropólogo). Aliás, foi o próprio Darcy Ribeiro quem incentivou Lelé a aprender como os índios construíam. Apesar de ter buscado referências na arquitetura antiga, Lelé sempre teve o cuidado de analisá-la no contexto de época, abstraindo suas lições e adaptando os sistemas construtivos aos novos materiais e técnicas atuais. Partindo do princípio que a concepção estrutural de um prédio é fundamental, Lelé não pode deixar de admirar a forma primitiva e intuitiva com que os índios Xinguanos construíam as suas cabanas, desenvolvendo uma tecnologia passada de geração em geração. Segundo ele:
24 Aloysio Campos da Paz, grande amigo de Lelé, é cirurgião-chefe e fundador da Rede Sarah de Hospitais do Aparelho Locomotor.
Figura 1 - Perspectiva externa da primeira proposta. Crédito dos desenhos e imagens em todo o texto: Arquivo Lelé

Figura 2 - Perspectiva interna da primeira proposta
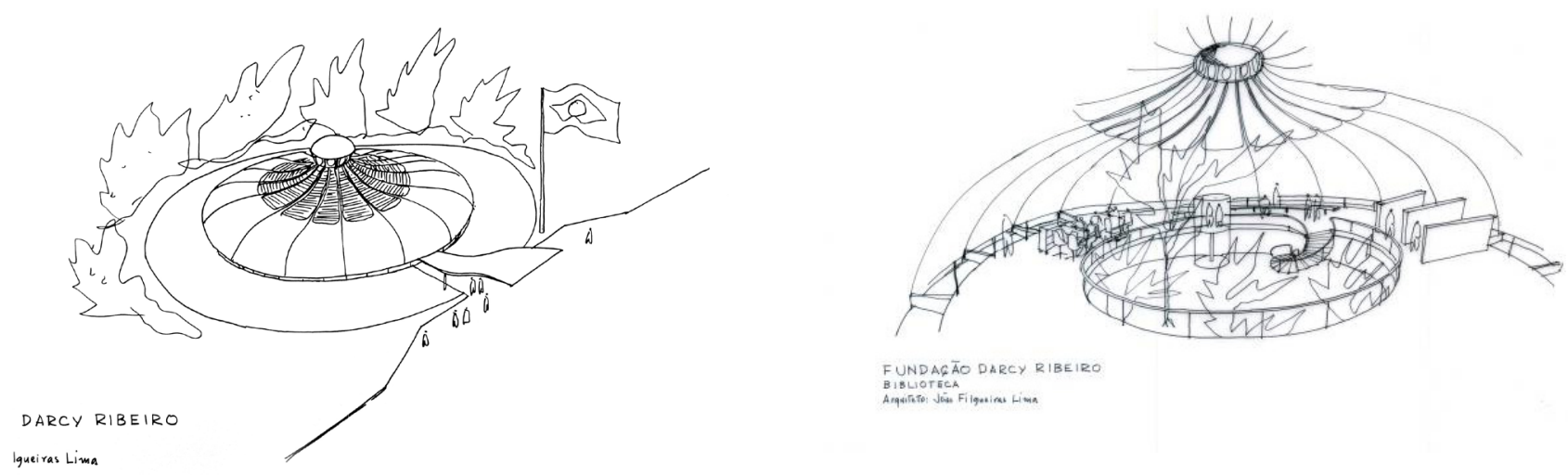

FUNDAGĀO DARCY RIBEIRC

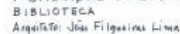


"A cabana dos índios é uma coisa linda. Possui ventilação, até um shed como esses que utilizo em meus trabalhos... tem uma cumeeira por onde sai o ar quente. (...) É possível identificar ainda o contraventamento, contra efeitos de vento. (...) No projeto da Fundação Darcy Ribeiro, a grande cobertura tem um sentido um pouco disso, pode-se interpretar tanto como uma nave espacial quanto como uma cabana indígena. Depende da sensibilidade de quem vê. Tem dois apelos: pode ser uma nave espacial pousada, porque é uma coisa leve, muito delicada, e pode ser uma cabana, pela forma. Não que eu tenha pensado em fazer isso. O que queria resolver realmente era a questão de um espaço que todo mundo dominasse, exatamente como Darcy Sempre foi: ele interagia com todo mundo. Nada como um círculo, uma forma circular, para criar esta unidade espacial" 25 .

O primeiro desenho de Lelé ${ }^{26}$ não difere muito das propostas futuras, que sofreram pequenas adaptações. Lembra uma grande tenda que abriga um espaço de planta circular em dois pavimentos, circundada totalmente por um jardim aquático, também circular, apenas interrompido pela passarela de acesso. Com o projeto já pronto, Lelé recebe um telefonema de Darcy Ribeiro, solicitando a criação de um "beijódromo". E começou a lhe explicar o que tinha em mente: "Seria um espaço ao ar livre, na grama, nos degraus - um espaço bem a gosto de Brasília, em que se podia fazer seresta, as pessoas poderiam estar em volta se beijando, namorando. Para uso noturno, principalmente"27. Lelé, então, elabora a segunda versão do projeto, situando o "beijódromo" do lado oposto ao acesso principal, um anfiteatro ao ar livre distribuído na encosta de uma elevação ajardinada contornando parcialmente o lago. A ligação do palco com o prédio se faria por uma passarela e a superfície do lago refletiria o céu estrelado de Brasília nas noites de seresta. $\mathrm{O}$ desenho entregue a Darcy segue acompanhado de uma
Figura 3 - Corte esquemático da primeira proposta sem o "beijódromo".

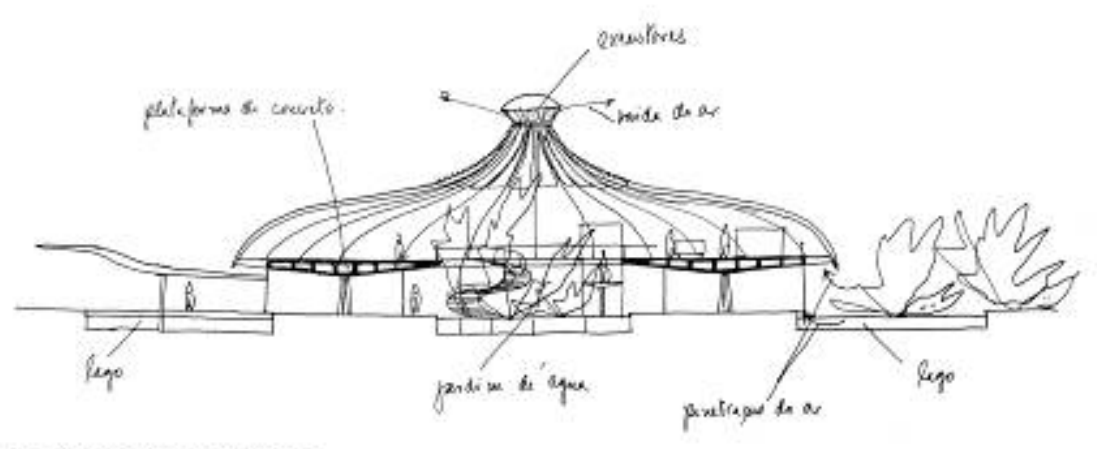

FUNDAGT̃O DARCY RIBEIRO

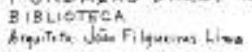


Dancy.

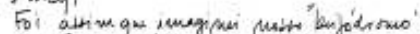

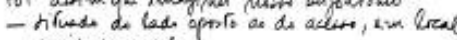

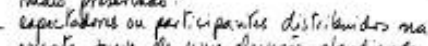

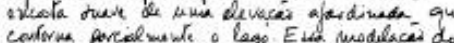

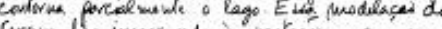

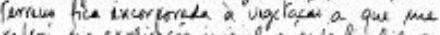

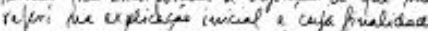
privipal resia a de der socila do príde.

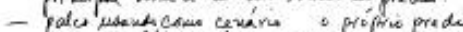

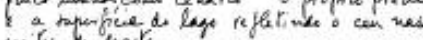
moilu de perests

- Rigezés de apois do palco com prídio
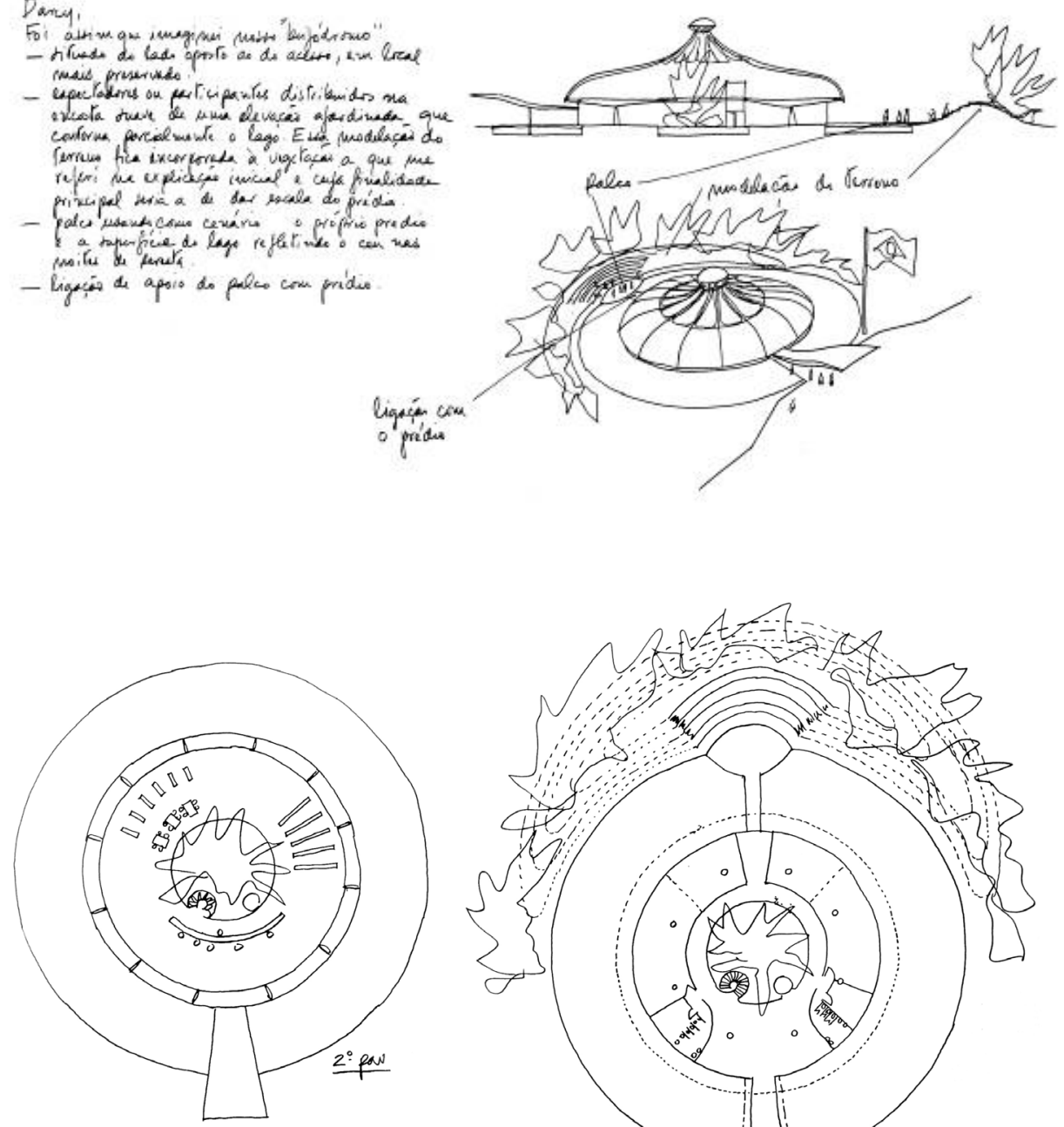

FUNDACĀO DARCY RIBEIRO BIBLIOTECA

Arquiteto : Joáu Filqueiras Lima

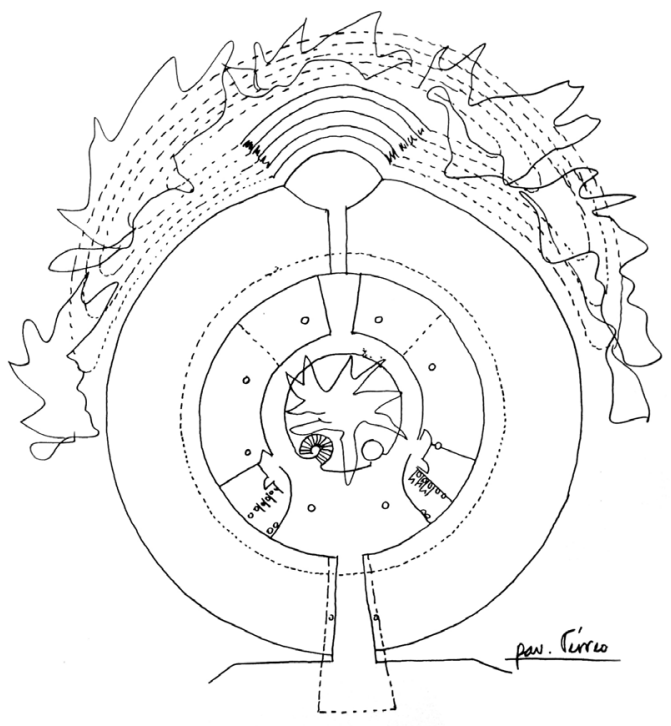

Figuras 4 e 5 - Corte e perspectiva da segunda versão do projeto, com a inclusão do "beijódromo".

Figuras 6 e 7 - Plantas do $2^{\circ} \mathrm{pa}$ vimento e do térreo da segunda versão do projeto.

Figura 8 - Maquete entregue a Darcy Ribeiro, com a inserção do "beijódromo" ao ar livre. 
28 LATORRACA, Giancarlo (Ed.), op. cit., p. 247 e LIMA, João Filgueiras. Fundação Darcy Ribeiro - Biblioteca. (Álbum de desenhos, A4). Manuscrito, [2009], s.p. ${ }^{29}$ FUNDAÇÃO DARCY RIBEIRO. Disponível em: <http://www. fundar.org.br/darcy_fundar.htm>. Acesso em 7 de julho de 2010.

${ }^{30}$ Entrevista concedida à autora em 20 de junho de 2010.

31 Darcy Ribeiro faleceu em 17 de fevereiro de 1997 e Berta Ribeiro em 17 de novembro do mesmo ano.

32 Reunião realizada no gabinete do reitor, em 07 de junho de 2008, na presença de Lelé, Paulo Ribeiro, sobrinho de Darcy Ribeiro e presidente da FUNDAR, Cláudia Estrela Porto, vice-diretora da FAU/ UnB e amiga de Lelé, Luis Motta, assessor de comunicação do reitor, e o jornalista Rodolfo Borges, da SECOM da UnB. segunda carta e da pequena maquete ilustrativa ${ }^{28}$.

Com o projeto preliminar definido, cabia agora a escolha do terreno. A moléstia avançava, Darcy Ribeiro sentia dores e não podia mais esperar. Apresentou o projeto ao então reitor da $\mathrm{UnB}$, João Cláudio Todorov, e, juntamente com Lelé, escolheram o terreno para a sua construção dentro do campus da UnB, próximo à reitoria. Darcy Ribeiro exultava de alegria.

"Tanta gente tem fundação, por que eu não? Pensando assim decidi criar a minha Fundação Darcy Ribeiro. Foi muito bem recebida, felizmente. $\mathrm{Mi}$ nha filha, a UnB, decidiu acolhê-la em seu campus e até construir sua sede e mantê-la. Em compensação, recebem minha biblioteca de 30 mil livros, o arquivo documental Berta/Darcy, meus quadros e objetos de arte. Ainda melhor que isso é o prédio que o Lelé projetou pra mim. Será um disco voador enorme, pousado no pedaço mais bonito do campus. A Sala de Leitura, com 250 metros de diâmetro, será prodigiosa. Sem janelas, porque toda translúcida, graças à cobertura que deixa passar luz. No andar térreo, ficam vários serviços, inclusive o arquivo Berta/Darcy, um centro de documentação visual sobre os índios do Brasil e um serviço de preprodução em CD-ROM das dissertações de mestrado e das teses de doutorado sobre educação. A novidade maior é que, com medo de minha FUNDAR parecer vetusta demais, consegui do Lelé fazer dela um beijódromo, que corresponderá, em Brasília, ao Sambódromo que criei no Rio. Trata-se de um amplo palco ao ar livre para serestas e leitura de teatro e poesia, defronte de uma arquibancada para duzentos olharem a lua cheia e se acariciarem. Eu, lá de longe, estarei vendo, feliz"29.

Segundo Lelé $e^{30}$, Darcy Ribeiro gostou tanto do projeto que ficava com a maquetezinha debaixo do braço, de um lado para o outro. De índole irrequieta, sempre pronto a dar uma nova sugestão, capitulou no último encontro com Lelé, emitindo a sua última impressão: "Lelé, faz tudo o que você quiser. Não quero dar mais nenhuma opinião, faz tudo o que você quiser".

Logo depois, Darcy Ribeiro faleceu, seguido de Berta Ribeiro ${ }^{31}$. Coube a Lelé lutar para que o sonho de Darcy se tornasse realidade. Na época, a administração central da UnB não se engajou com afinco na construção do projeto e ele ficou engavetado. Em 2008, a Fundação Darcy Ribeiro contata novamente Lelé para dar prosseguimento a este belo sonho. O pontapé inicial foi dado numa reunião com o reitor da $\mathrm{UnB}$, Roberto Armando Ramos de Aguiar ${ }^{32}$, na qual Lelé salientou a importância histórica da construção desta obra no campus da UnB, e para ele mesmo, amigo íntimo de Darcy Ribeiro. Apresentou o projeto aprovado por Darcy, definiu o tamanho do terreno $(80 \mathrm{~m} \mathrm{x} 80 \mathrm{~m})$ e estimou o preço da obra em 5 milhões de reais. Neste mesmo dia, emocionou-se ao constatar que o terreno inicial, escolhido pelo próprio Darcy Ribeiro, localizado na 
"Praça Maior da UnB", entre a reitoria e o ICC norte, estava livre e poderia acolher a sua "maloca".

O reitor Roberto Aguiar ouviu com atenção o relato de Lelé e demonstrou verdadeiro interesse na realização do projeto, mas contingências financeiras o postergou mais uma vez. Um ano depois, o reitor da UnB, José Geraldo de Sousa Junior, apresenta o projeto à comunidade acadêmica da UnB e à sociedade, através de uma Audiência Pública ${ }^{33}$. Aceito sem restrições, precisava ainda contar com o apoio governamental para liberação da verba necessária. Dois meses depois de assinado o termo de permissão de uso entre a Fundação Universidade de
Brasília (FUB) e a Fundação Darcy Ribeiro (FUNDAR) ${ }^{34}$, o último entrave foi vencido. O Poder Executivo, através de seu ministro da Cultura, Juca Ferreira, assina ${ }^{35}$ um convênio de cooperação para a construção da fundação, investindo 8,5 milhões de reais na obra.

A terceira versão, apresentada por Lelé nesta Audiência Pública, traz algumas modificações aos projetos anteriores. O "beijódromo", que inicialmente seria descoberto, ganha uma cobertura em forma de concha em telha metálica pré-pintada branca para dar maior flexibilidade ao espaço, adaptando-o aos propósitos atuais da FUNDAR.

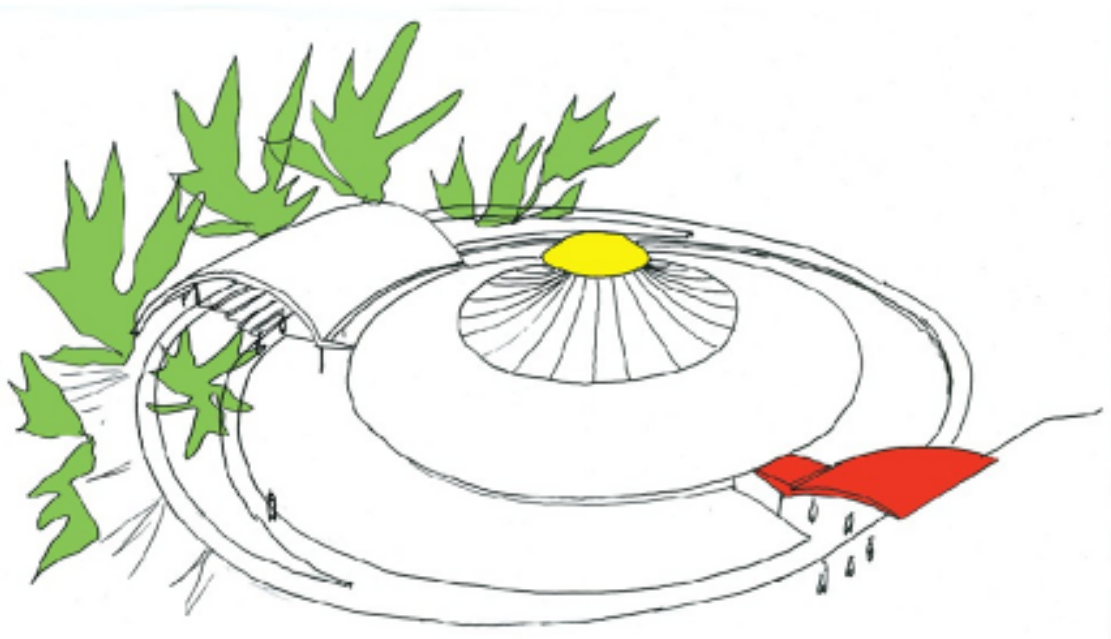

Figura 9 - Perspectiva externa da terceira versão do projeto, com a marquise cobrindo o "beijódromo" (anfiteatro).

\footnotetext{
Em 20 de maio de 2009.

35 Em 10 de maio de 2010.
} 


\section{O PROJETO EXECUTIVO}

\section{Situação}

Para melhor adaptar o projeto ao sítio, preservando as árvores existentes, o terreno foi deslocado um pouco daquele escolhido por Darcy Ribeiro. Embora nas cercanias e ainda situando-se na "Praça Maior", está mais próximo da Via VC13, a sudeste, tendo como referência a noroeste, o prédio da Reitoria, e a sudoeste o Instituto Central de Ciências. A área total de construção $\left(1.989,50 \mathrm{~m}^{2}\right)$, ao custo de aproximadamente 2.000 reais o $\mathrm{m}^{2}$, se distribui como área construída no térreo $\left(706,62 \mathrm{~m}^{2}\right)$, no pavimento superior $\left(596,89 \mathrm{~m}^{2}\right)$, projeção da marquise $\left(54,60 \mathrm{~m}^{2}\right)$, arquibancada e área externa $\left(252,92 \mathrm{~m}^{2}\right)$, tendo como área de projeção da cobertura do edifício 1.085,19 $\mathrm{m}^{2} \mathrm{e}$ área de projeção da cobertura da arquibancada $467,53 \mathrm{~m}^{2}$.

\section{Programa}

A distribuição dos ambientes na proposta inicial reflete o programa estabelecido a priori por Darcy Ribeiro. No pavimento térreo seriam alocados o hall de entrada, área de exposições, sala para seminários e manutenção de livros, e o "beijódromo". O pavimento superior, sem pilares e totalmente flexível, acomodaria a biblioteca propriamente dita. As modificações propostas pela FUNDAR fizeram com que a parte térrea ficasse mais compartimentada, acolhendo agora a recepção, foyer de exposições, área para estar e café, três salas de aulas, administração, almoxarifado, sala para restauro e produção de eventos, sanitários e dois camarins.

A escada circular, se insinuando antes dentro do jardim aquático central, integrava o espaço inferior e superior. Agora, retilínea, com guarda corpo em vidro, se desloca para fora do círculo central, evitando, desta forma, a interferência sonora

Figuras 10 e 11 - Vista aérea da UnB com a inserção da Fundação Darcy Ribeiro e Planta de Localização do prédio
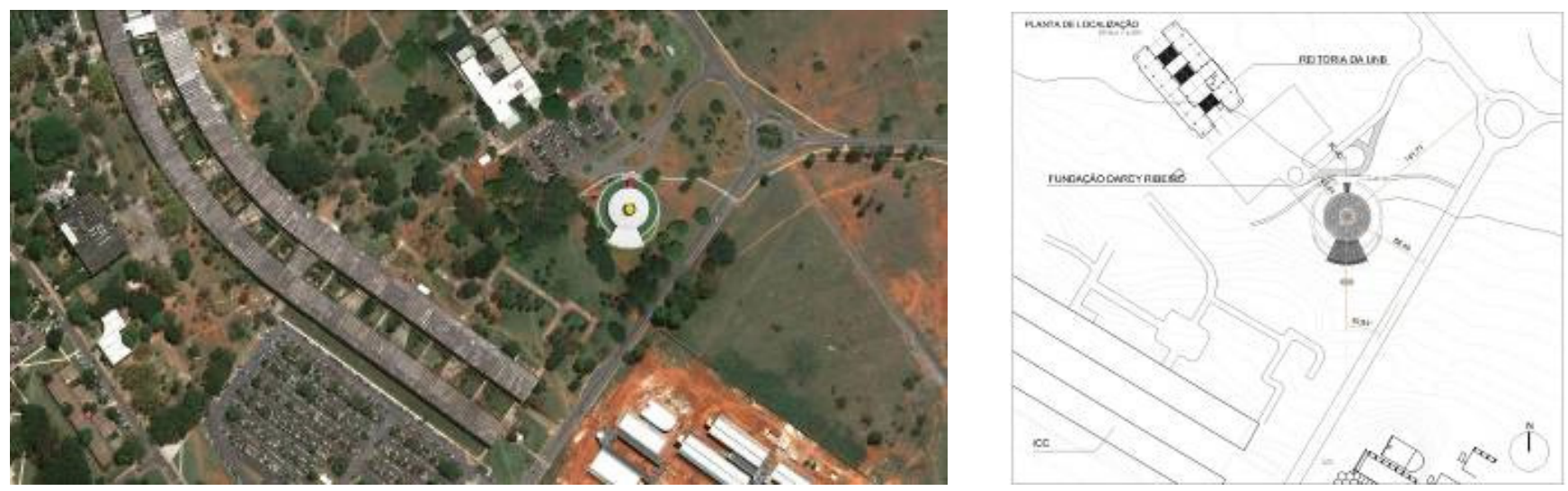
na biblioteca, situada no pavimento superior, pelo uso intensivo da parte de baixo pelos estudantes. Lelé, astucioso, contorna o problema do ruído excessivo com uma solução engenhosa: bloqueia a parte inferior com um círculo de vidro delimitando o jardim central, que prossegue até o pavimento superior, faceando a laje do primeiro piso e se transformando no guarda-corpo da biblioteca, a 1,10 m de altura. Evita, desta forma, a descontinuidade do espaço, já que integrado visualmente pelo jardim central. O elevador metálico, com fechamento em vidro, permanece na periferia do círculo central ajardinado.

Se antes o projeto tinha uma informalidade maior, bem a gosto de Darcy, hoje, por questões de segurança, teve de ser adaptado. Além de câmaras de controle, o piso superior sofreu outras alterações. $\mathrm{O}$ espaço completamente livre e informal, pensado originalmente por Darcy Ribeiro para a biblioteca, onde o usuário teria acesso direto aos livros, puxando estantes com rodas, agora é contornado por vidro que protege a área do acervo bibliográfico, restringindo o acesso. Para evitar uma desintegração maior, Lelé desenvolve um detalhe de vidro temperado, de $2 \mathrm{~m}$ de altura, fixado só no piso, sem montante, protegendo sem criar um elemento hostil. Segundo Lelé, "o arquiteto tem obrigação de entender que o projeto sempre é o menos ruim, não é o ótimo, e é preciso fazer concessões indispensáveis ao seu bom funcionamento, sem descaracterizar completamente o espaço" ${ }^{37}$.
O piso superior recebe ainda uma sala com ar-condicionado, para melhor controle de umidade do acervo de Darcy e Berta Ribeiro, salas de estudo informatizadas e de pesquisa, além de uma área de exposição temporária do acervo da fundação. Todas as divisórias nesse espaço são de vidro e engastadas no chão através de um suporte de aço. À exceção das salas do acervo, para as quais foi previsto um teto rebaixado em policarbonato, todas as outras salas recebem divisórias de vidro soltas de $2 \mathrm{~m}$ de altura.

No pavimento térreo, o teto e as divisórias entre os ambientes são de gesso. Porém, aquelas por onde passam tubulações e precisam ser impermeáveis, como as dos banheiros, são de argamassa armada feita no local.

No térreo, uma porta, diametricamente oposta à entrada principal, conduz o usuário ao "beijódromo", que agora passa a ser um auditório com 200 lugares. Uma parede curva em argamassa armada funciona como um anteparo, resguardando o acesso ao bloco principal e, servindo, ao mesmo tempo, de fundo do palco elíptico elevado. Acoplada a ela, uma pequena sala de som e um espaço para depósito do auditório.

\section{Estrutura}

Na idéia inicial do projeto, Lelé hesitava entre uma cobertura em casca de argamassa armada ou mista em plástico e aço. Pondera que a primeira opção exigiria formas e escoramentos complicados, executados no local. Já a segunda, mais
${ }^{37}$ Entrevista concedida à autora em 20 de junho de 2010. 

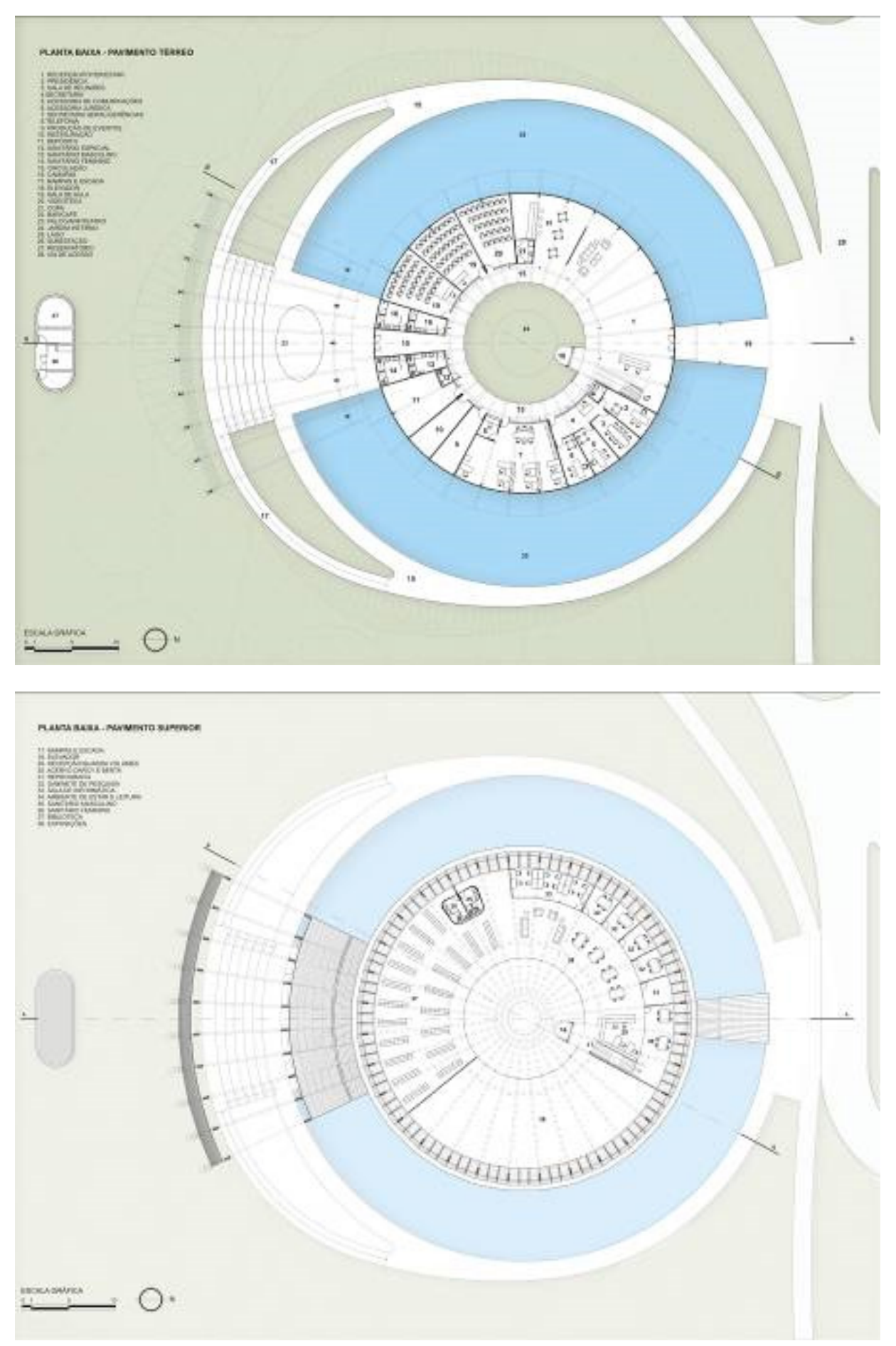

Figura 12 - Planta baixa do térreo

Figura 13 - Planta baixa do piso superior

Figuras 14 e 15 - Fachadas lateral e principal do prédio
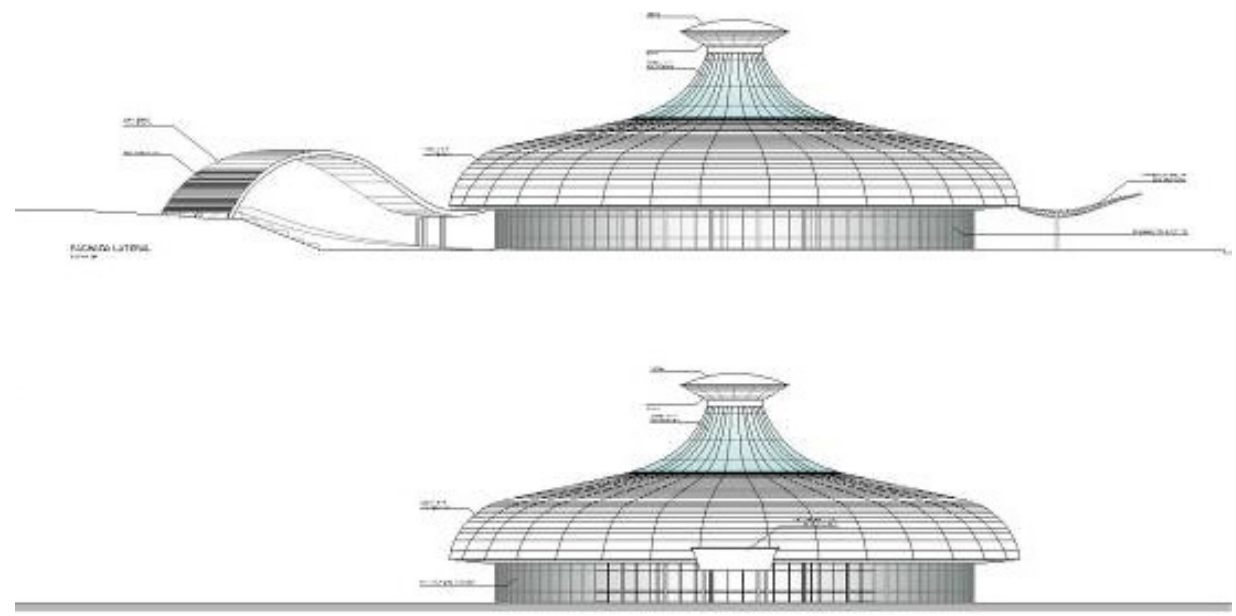
leve e econômica, teria de lançar mão de uma tecnologia só disponível, na época, no Centro de Tecnologia da Rede Sarah. A estrutura do primeiro piso, concebida em concreto, se resumia a uma grande plataforma monolítica em caixão perdido, com um furo central de $12 \mathrm{~m}$ de diâmetro, e apoiada por meio de rótulas em oito pilares em tronco de cone. As vigas da grande cobertura se apoiavam nos balanços dessa estrutura, como é hoje.

Há quatorze anos, quando o projeto surgiu, Lelé começava suas experiências com aço na Rede Sarah, e o Brasil ainda era incipiente na produção desse material para estruturas especiais. Agora o cenário é diferente. Com a evolução da tecnologia do aço e dominando o material, Lelé não titubeia em usá-lo na nova concepção estrutural. Com este material, impõe um ritmo de velocidade maior à obra, com a industrialização de seus componentes.
O edifício circular em dois pavimentos, com 32,20 m de diâmetro interno e $37 \mathrm{~m}$ de diâmetro de cobertura, tal uma tenda de circo (ou uma maloca, como preferia Darcy Ribeiro), se lança para o alto em sua parte central, atingindo 14,80 m no topo da cúpula, que acolhe embaixo um espaço circular ajardinado, de $12 \mathrm{~m}$ de diâmetro e pé-direito duplo.

A cobertura é composta de telhas especiais dobradas em chapa pré-pintadas de aço galvanizado branco, com proteção interna de bidim e forro obilongo metálico por baixo. Na parte correspondente à projeção do jardim interno, uma grande clarabóia, garantindo a luminosidade natural, é formada por telhas de policarbonato transparente alveolado com 6 mm de espessura, que se sobrepõem uma às outras até o anel de compressão da cúpula, ela própria uma veneziana metálica com cobertura em fibra de vidro. Aliás,
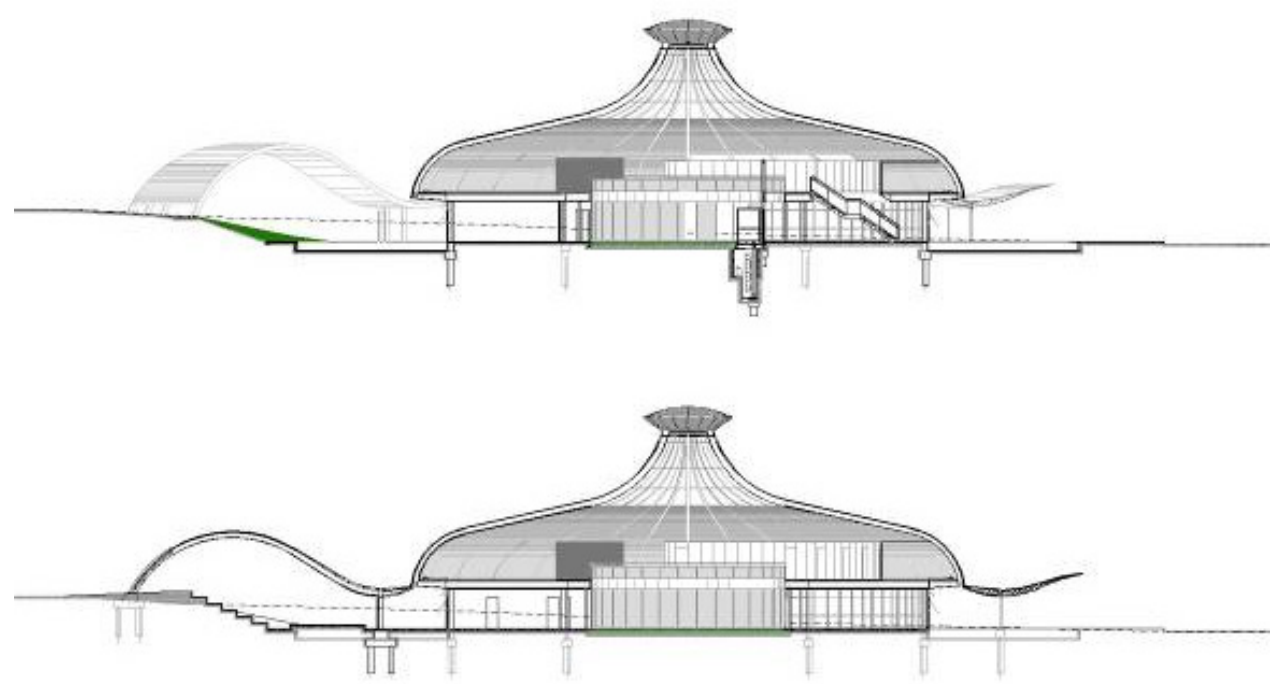

Figuras 16 e 17 - Cortes esquemáticos do prédio - Corte BB (superior) e Corte AA (inferior). 
38 Perfil metálico em "I", com 40 $\mathrm{cm}$ de altura e banzos inferior e superior de $20 \mathrm{~cm}$.

39 Perfil metálico em "I", com 45 $\mathrm{cm}$ de altura e banzos inferior e superior de $20 \mathrm{~cm}$.

${ }^{40}$ De $6 \mathrm{~cm}$ de espessura.

$41 \mathrm{O}$ balanço interno, próximo ao círculo central, é de 1,60 m, e o externo, na periferia que acolhe as vigas radiais da cobertura, de 2,70 m.

42 Perfil metálico em "I", com 35 $\mathrm{cm}$ de altura e banzos inferior e superior de $20 \mathrm{~cm}$, com altura variável apenas no balanço de 2,0 $\mathrm{m}$. na primeira versão do projeto, Lelé chegou mesmo a cogitar revestir todo este espaço central com fibra de vidro, uma vez que esta era a única opção viável, a produção de policarbonato ainda não tendo se instalado no Brasil.

A estrutura da cobertura, composta de 32 vigas curvas radiais em perfil "I"38, apóia-se, internamente, no anel de compressão da cúpula, de $2,60 \mathrm{~m}$ de diâmetro, e, no outro extremo, está engastada na ponta do balanço externo do pórtico do piso superior, composto também de 32 vigas radiais em perfil "I" de alma cheia ${ }^{39}$. Estas vigas, por sua vez, são engastadas em 32 pilaretes metálicos, dispostos na periferia da construção, e nas vigas transversinas que formam o anel circular interno, distribuindo sua carga para 16 pilares metálicos tubulares, situados entre duas linhas de forças principais. Ao deslocar lateralmente os pilares internos, Lelé simplifica o esquema estrutural, reduzindo-os. Todos os pilares estão apoiados no solo.

O sistema como um todo, devido às cargas do vento, cria empuxos laterais, fazendo com que os pilares da periferia absorvam momentos. $\mathrm{O}$ forte embasamento estrutural de Lelé o conduz à solução correta, integrando a laje em concreto ${ }^{40}$ do primeiro piso à estrutura em aço. $\mathrm{O}$ concreto, ao penetrar nas vigas transversinas, solidariza a laje de concreto com a estrutura metálica, eliminando a ferragem negativa. Desta forma, ela absorve os empuxos e participa do travamento de todo o sistema, dando o contraventamento necessário à estrutura.
Ao nervurar a laje, Lelé diminui sua espessura, evitando também a necessidade de contrapiso. Outra vantagem é que este sistema elimina o cimbramento para a concretagem das lajes, agilizando a obra.

A parede em alvenaria de concreto, que fecha internamente as salas do térreo, ajuda também neste contraventamento estrutural, uma vez que o pórtico metálico possui balanços significativos dos dois lados ${ }^{41}$. Para o fechamento lateral do térreo, Lelé desenvolve um detalhe interessante. Ele arremata a esquadria em vidro, que faceia os pilares periféricos, com uma canaleta metálica em chapa dobrada, por onde correm as instalações.

A estrutura da marquise de entrada, também metálica, sofreu modificações para se ajustar ao ritmo acelerado da obra. Pensada inicialmente em treliça, será composta com perfis "I", de inércia variável, encontrados facilmente no mercado.

$\mathrm{Na}$ parte posterior do prédio, o terreno foi nivelado com a terra resultante da escavação do lago, formando taludes de aproximadamente $2 \mathrm{~m}$ de altura que, parcialmente revestido com placas de concreto, forma um pequeno teatro de arena. O palco ocupa a parte externa do lago e comunica-se com o prédio através de uma ponte.

Uma cobertura em forma de concha metálica branca fecha o espaço do "beijódromo". Com forro em chapa dobrada, ela se apóia em 10 vigas curvas de perfil "I" ${ }^{42}$, que não toca o pórtico do pavimento principal. Trata-se de uma estrutura independente, apoiada diretamente na fundação, pelo lado externo, e 

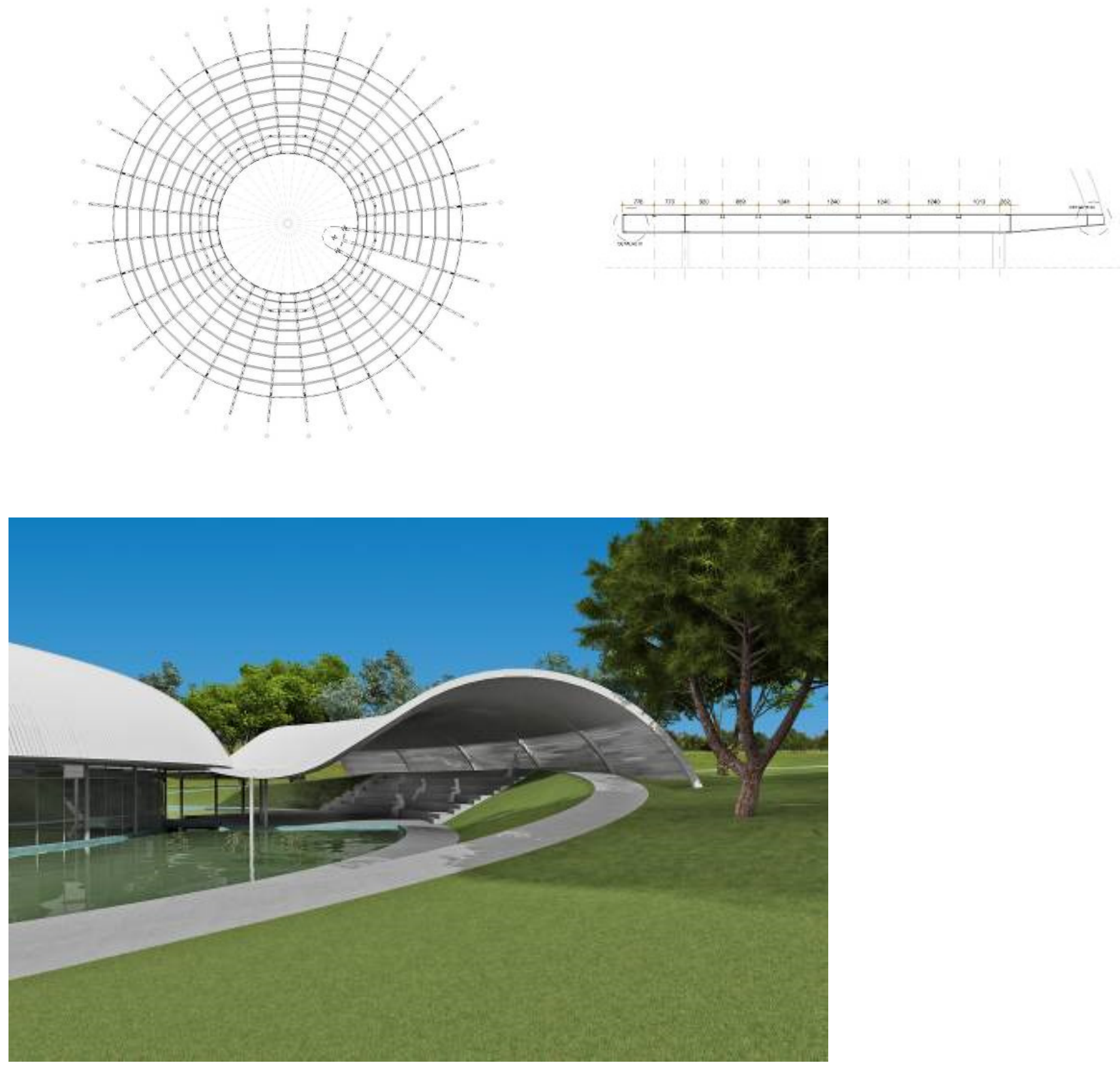

Figura 18 - Esquema estrutural do primeiro piso.

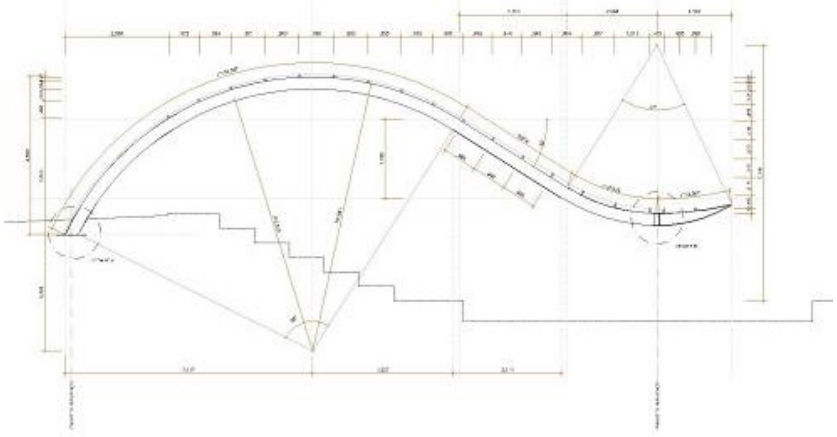

Figura 19 - Detalhe do pórtico metálico com balanços dos dois lados. O concreto, ao penetrar nas vigas transversinas, solidariza a laje de concreto com a estrutura metálica.

Figura 20 - Teatro de arena coberto.

Figura 21 - As vigas que formam a cobertura do "beijódromo" se apóiam diretamente na fundação e em 5 pilares radiais tubulares na parte interna, sendo independentes do bloco principal. 
Figura 22 - A luz penetra através dos brises metálicos situados na parte posterior do anfiteatro.

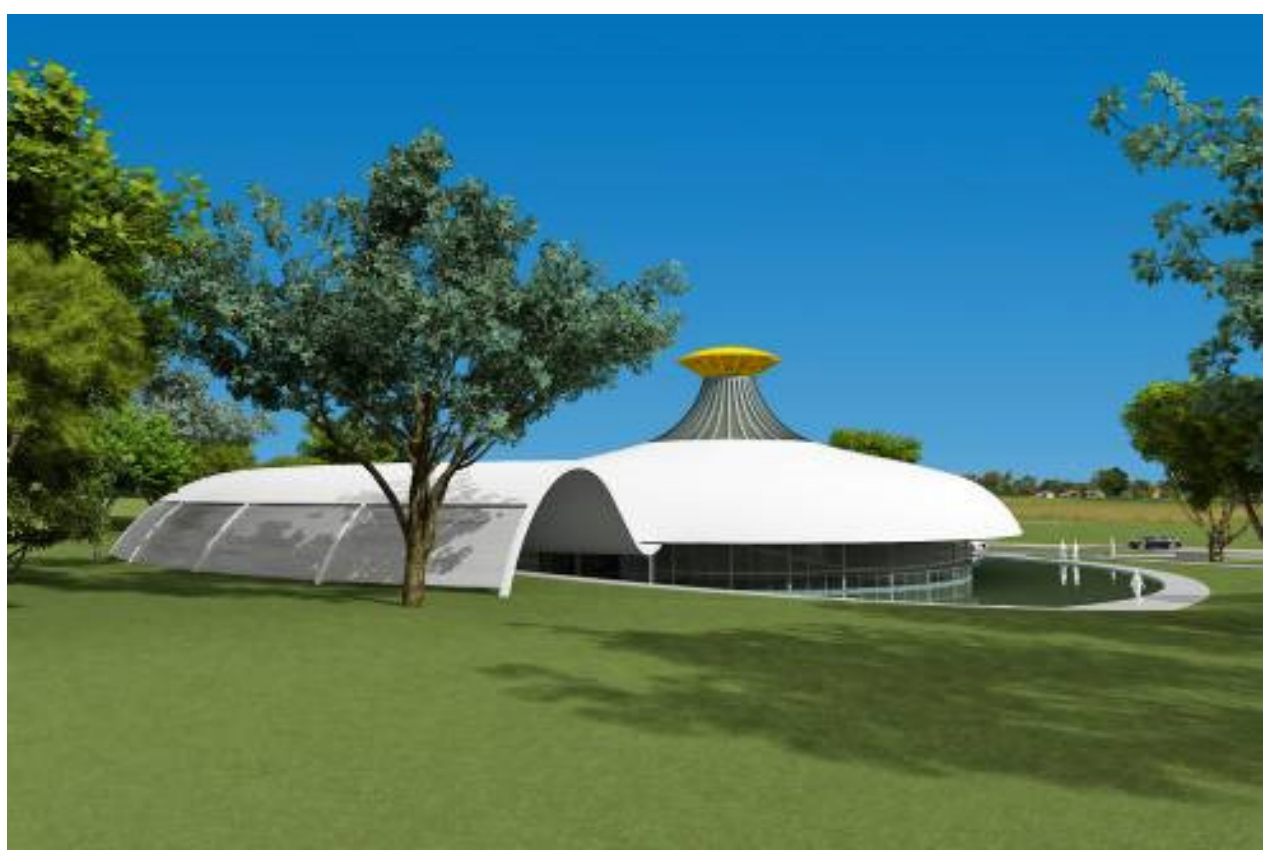

em 5 pilares radiais tubulares, por onde desce a água pluvial, na parte interna. Brises metálicos fixos entre as vigas radiais se integram à cobertura, correndo do solo até a altura de 2,42 $\mathrm{m}$ na parte posterior do anfiteatro. Fazem o papel de uma veneziana, deixando a luz penetrar no jardim que se insinua por dentro, mas evitando o calor excessivo do sol.

Desejando dar maior flexibilidade ao espaço, Lelé o mobília com o indispensável para uma boa festa, inserindo na área interna de vegetação uma mesa de controle de som e de luz, de onde se podem projetar imagens numa tela que cai automaticamente do teto.

A última contribuição ao projeto, porém, são placas verticais metálicas, que fecham lateralmente o anfiteatro dos dois lados. Desejando manter o caráter informal que Darcy Ribeiro tanto queria e resolver o problema do escurecimento para projeção durante o dia, Lelé desenha grandes estruturas pivotantes retilíneas, que chegam quase até o teto. Largas de $1 \mathrm{~m}$, elas possuem altura variável de acordo com a cobertura, alcançando a mais alta 5,20 m.

Estas placas, funcionando como brises, podem ser fechadas ou abertas, controlando a incidência da luz e proporcionando maior conforto sonoro. Ao desenhá-las, Lelé pensou em elementos ligados ao solo, como árvores que se integrariam aos jardins adjacentes. Escolheu pintá-las de um lado de verde 


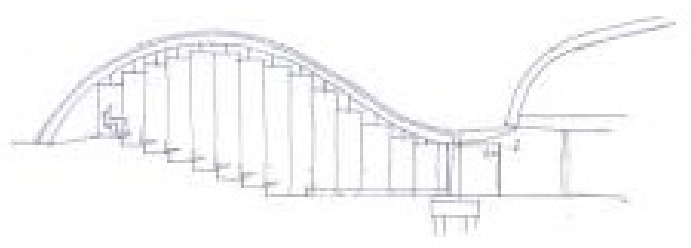

Figura 23 - Planta baixa do auditório. Acoplado à parede curva em argamassa armada que protege a entrada do bloco principal, uma pequena sala de som e outra para o depósito do auditório.

Figura 24-Grandes placas metálicas pivotantes fecham o auditório lateralmente.

e do outro de azul, nas cores da bandeira da UnB. Prestaria, assim, sua homenagem à universidade, lembrando que foi Lucio Costa quem sugeriu estas cores a Darcy Ribeiro.

Embora as cargas não sejam grandes, da ordem de 16 toneladas, Lelé optou por uma fundação em estaca devido ao solo fraco e também para absorver os momentos nos pilares da periferia que chegam a ser de 8 t.m. O melhor, talvez, fosse fazer estacas pré-moldadas ou em aço, porém, elas não estavam disponível no mercado a curto prazo. Daí a opção pela estaca "Strauss", dita rasa, com $9 \mathrm{~m}$ de profundidade, trabalhando mais por atrito.

\section{Conforto Ambiental}

$\mathrm{Na}$ proposta inicial, além de circundar todo o prédio com espelho d'água, Lelé propôs que o círculo interno central também fosse um jardim aquático que integraria os dois pavimentos do edifício, garantindo a umidade necessária aos livros da biblioteca, no pavimento superior. Porém, pensando melhor, chegou à conclusão que este sistema criaria um fluxo vertical de baixo para cima, a circulação da umidade não acontecendo conforme gostaria no entorno.

De forma que, na solução definitiva, restringiu o espelho d'água apenas na periferia, formando um anel com diâmetro externo de $52 \mathrm{~m}$. Criou, porém, nebulizadores de água no lago que contorna o 
prédio. Nos períodos secos, eles seriam acionados, criando uma espécie de névoa, que poderia dar ao edifício um "ar extraterreno". Essas gotículas de água, por evaporação, resfriam o ar que penetra no ambiente e é extraído, por convecção forçada eventualmente por um grande exaustor situado no topo da cobertura. Esta solução aumenta o teor de umidade do ar insuflado e, conseqüentemente, estabelece um micro clima interno mais ameno e necessário à preservação dos livros.

$\mathrm{O}$ ar é introduzido pelas janelas das salas que circundam todo o ambiente do térreo e, na parte superior, evitando a entrada de insetos, por orifícios de $2 \mathrm{~mm}$ do beiral do anel circular externo, fechado por uma chapa de ferro perfurada. $\mathrm{O}$ ar fresco, penetrando pela periferia do prédio, circula por todo o ambiente antes de ser extraído por cima.

Engenhoso, Lelé evita usar exaustores do mercado, muito barulhentos. Constrói o seu próprio, de rotação baixa e silencioso, com diâmetro aproximado de 2,5 $\mathrm{m}$, acoplado na cúpula e dissimulado por uma rosácea em fita metálica. Não é uma idéia nova, ele já havia testado o mesmo sistema no auditório do Tribunal de Contas da União de Salvador ${ }^{43}$.
Figura 25 - Esquema da solução adotada para garantir o conforto térmico: o ar insuflado é resfriado pelos nebulizadores situados no lago antes de penetrar lateralmente no edifício.

Figura 26 - $O$ exaustor é acoplado à cúpula e fica dissimulado por uma rosácea metálica.
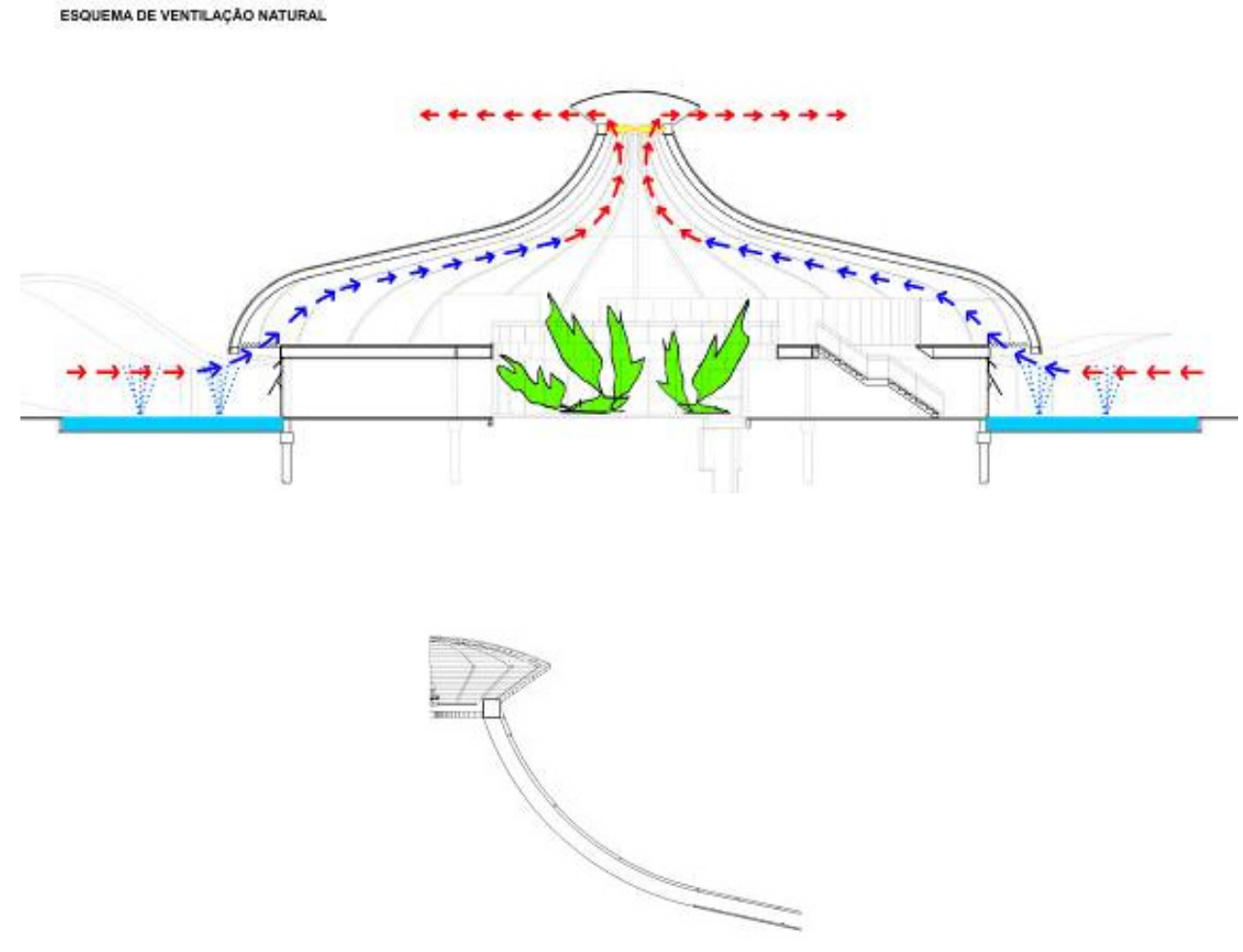


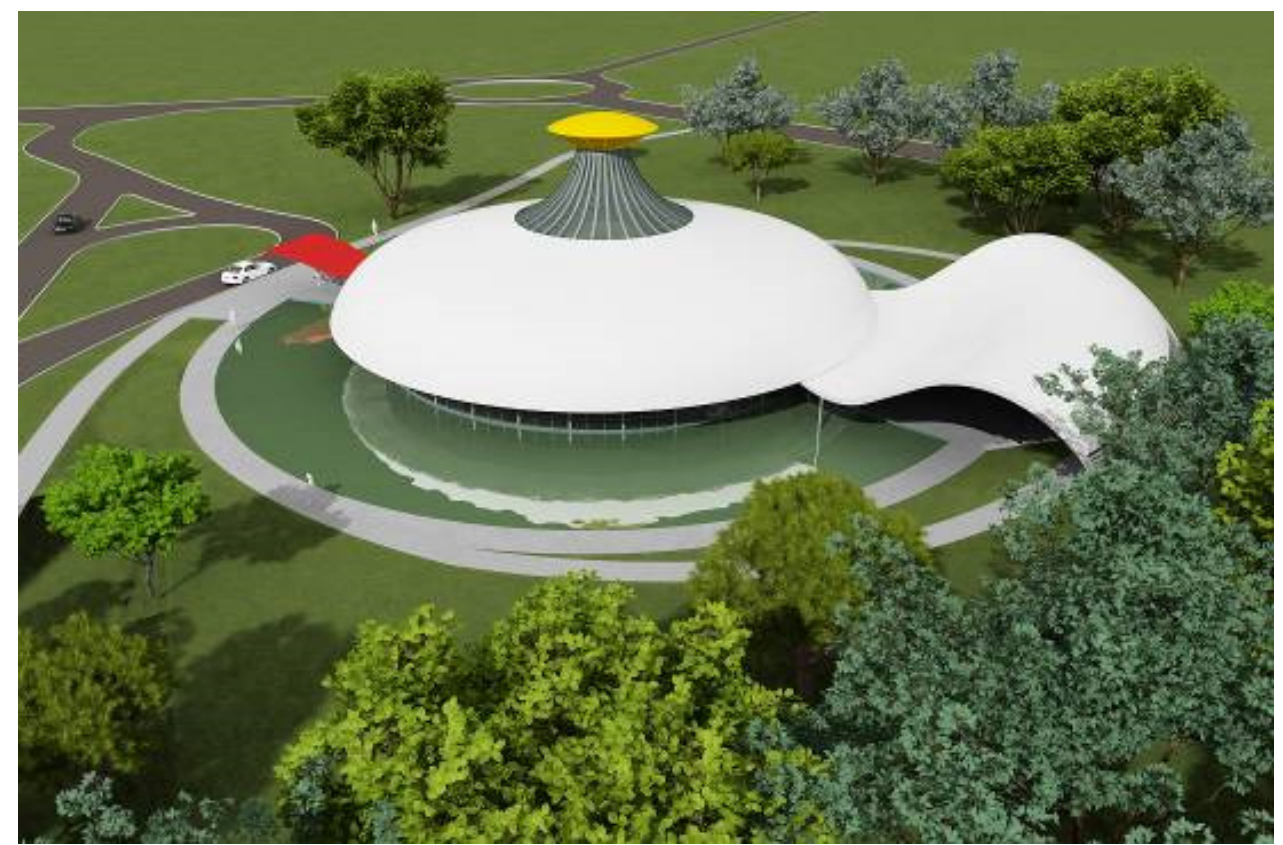

\section{Paisagismo}

Para dar escala ao prédio, Lelé imaginou, desde o início, um fundo verde contornando o lago e, principalmente, o "beijódromo", que deveria estar protegido por árvores. Também nunca visualizou o lago apenas como um espelho d'água de cunho estético, sem plantas. Sempre desejou ter "um jardim aquático", por isso projetou-o com $60 \mathrm{~cm}$ de profundidade para acolher as ninféias, a mesma solução adotada no Hospital Sarah do Rio de Janeiro, inaugurado em 2009.

\section{O DEVER CUMPRIDO}

Discreto e autocrítico ao extremo, Lelé sempre ficou à margem da fama.
Concentrou sua energia em pesquisar e produzir. Pode ser considerado quase um autodidata. Durante a faculdade, teve como mentor intelectual e artístico Aldary Toledo. Na prática profissional, chamou-lhe atenção a construção industrializada que propunha o alemão Mies van der Rohe, e os acabamentos primorosos em concreto e aço propostos pelo austro-americano Richard Neutra. Fiel aos seus princípios de não abrir mão da luz e ventilação naturais, estudou profundamente o finlandês Alvar Aalto e o dinamarquês Arne Jacobsen. Mestre, só teve um: o carioca Oscar Niemeyer. Ele "é a pessoa que mais me influenciou não só como arquiteto, mas também como ser humano" ${ }^{44}$, afirma. Despretensioso e ainda exaltando aquele que admira, costuma dizer: "Oscar
Figura 27 - Uma densa vegetação resguardará o espaço do "beijódromo".

44 LIMA, João Filgueiras. "Esse é Lelé”. Trip. São Paulo, nº 185, Fevereiro, 2010, p. 14. 

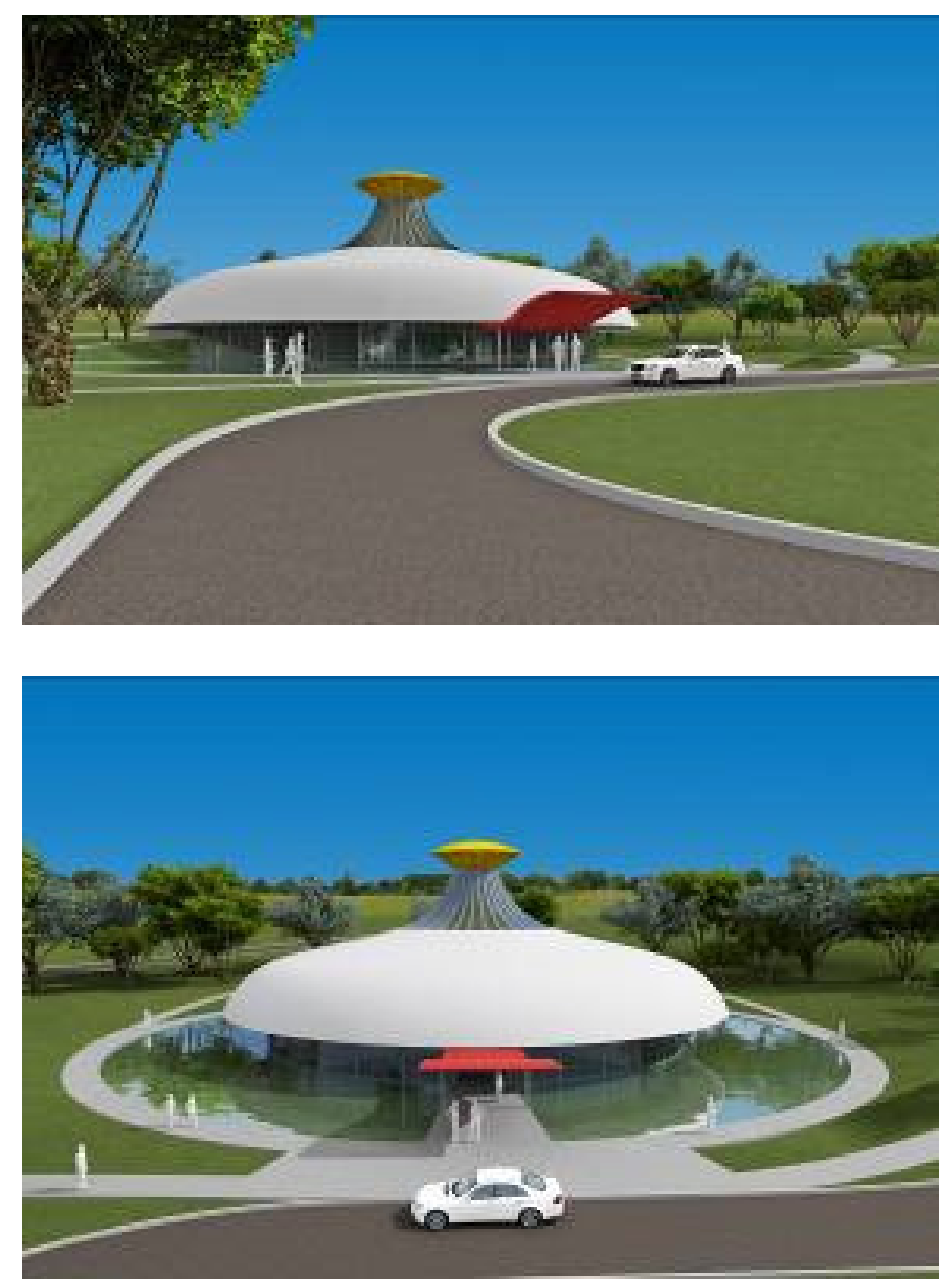

Figuras 28, 29, 30 e 31 - Beijódro-

mo: a última morada de Darcy

Ribeiro
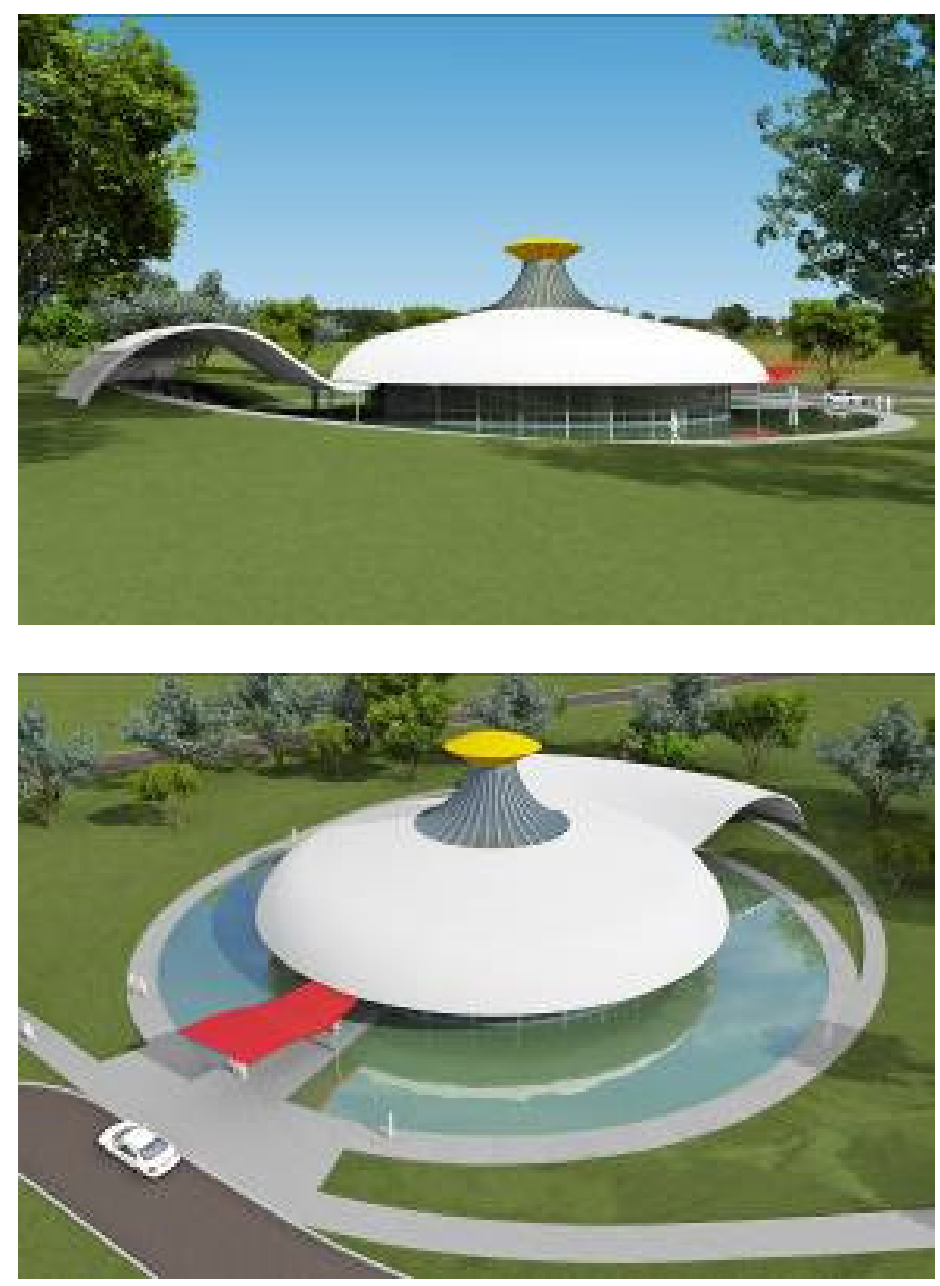
Niemeyer tem verdadeiras obras-primas, já eu não tenho nenhuma"45.

A história mostra o contrário. Se partirmos da definição que obra-prima é aquela "que devia realizar todo artesão aspirante a mestre" ${ }^{\prime 6}$, o difícil seria escolher qual, dentre todas as obras tecnologicamente criativas que Lelé desenhou nos últimos 50 anos, a que melhor ilustra o domínio que possui na arte de construir. Cada uma tem uma particularidade que emociona: o detalhe, o processo construtivo, a funcionalidade, a beleza que alimenta o espírito.

Ele não se tornou "mestre" por acaso. Foi, antes de tudo, um arquiteto inventor. As soluções de conforto natural, as aberturas tipo shed, a necessidade de criar equipamentos próprios, o design, a industrialização dos componentes construtivos, tudo isto faz parte de sua arquitetura. Um arquiteto que literalmente "pôs a mão na massa", que criou laboratórios de pesqui$\mathrm{sa}^{47}$ e trabalhou duro para dominar o processo como um todo: do desenho à obra.

Lelé não desenhou um memorial, menos ainda uma fundação, biblioteca ou "beijódromo"; desenhou o sonho do amigo Darcy Ribeiro, sua última morada, a casa que ficou the devendo desde os anos
1960, quando, desbravando a imensidão do cerrado, se impressionava com o céu repleto de estrelas que se confundia com a linha do horizonte. As estrelas ainda cintilam neste céu que será mesmo palco de serestas. O horizonte, porém, não é mais o mesmo. Não o da UnB, doravante tingido por um símbolo nela pousado suavemente, uma "espaçonave" que descansa trazendo o pensamento de Darcy Ribeiro. O tempo suficiente para aguçar a curiosidade dos povos, fazê-los viajar através de suas idéias, mantendo vivo o espírito de vanguarda deste que foi um verdadeiro brasileiro.

Darcy Ribeiro foi mais que um intelectual, foi um realizador que não tinha medo da morte. "A morte é apagar-se, como apagar a luz. Presente, passado e futuro? Tolice. Não existem. A vida vai se construindo e destruindo. O que vai ficando para trás com o passado é a morte. $\mathrm{O}$ que está vivo vai adiante"48. Darcy Ribeiro continua vivo. $\mathrm{E}$ vivo permanecerá graças aos esforços de muitos, mas especialmente de Lelé, para quem a realização deste projeto era uma questão de honra. "Eu fiquei mais ou menos depositário do desejo do Darcy, essa que é a verdade, o único depositário"49, diz ele emocionado, com a sensação do dever cumprido.

Cláudia Estrela Porto - Professora Titular da Faculdade de Arquitetura e Urbanismo da Universidade de Brasília. Arquiteta e urbanista (UnB, 1984), Mestrado (Art Et Archéologie - Université de Paris I Panthéon Sorbonne, 1990), Doctorat de 3ème Cycle (Université de Paris I Panthéon Sorbonne, 1993), Pós-Doutorado (Agência RFR, Paris), Pós-Doutorado (School of Planning and Architecture ,Delhi). Desde 1990, coordena vários Acordos Internacionais, possibilitando o intercâmbio de estudantes da FAU/UnB com Universidades na Itália e na França.

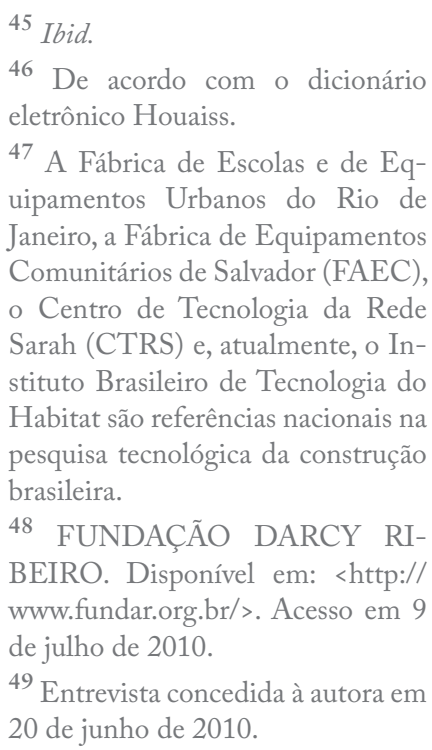

${ }^{49}$ Entrevista concedida à autora em 20 de junho de 2010. 